\title{
A Matter of Method: British Aristotelianism and the New Science*
}

Francesco Giuseppe Sacco ${ }^{\dagger}$

\begin{abstract}
Since long, the origins of modern science have been a topic of debates and controversies between continuist and discontinuistic historical approaches. Despite their differences, these approaches shared the emphasis on scientific methodology. But in the last decades of the twentieth century, historians and philosophers of science proposed critical approaches to methodology which radically altered the debate on the origins of modern science. Two historians, Steffen Ducheyne and Marco Sgarbi have recently offered a reappraisal of the traditional continuist theses, with respect to the influence of British Aristotelianism on Newton and early modern Empiricist philosophers. This paper aims to evaluate their impact on current historiographical debates, and will also offer some criticism of their main theses.
\end{abstract}

Keywords: aristotelianism - Newton - empiricism - scientific methodology - historiography

\section{Resumen}

Desde siempre, los orígenes de la ciencia moderna han sido un tema de debates y controversias entre enfoques históricos continuistas y discontinuistas. A pesar de sus diferencias, estos enfoques comparten el énfasis en la metodología científica. Pero en las últimas décadas del siglo XX, los historiadores y los filósofos de la ciencia propusieron enfoques críticos de la metodología que alteró radicalmente el debate sobre los orígenes de la ciencia moderna. Dos historiadores, Steffen Ducheyne y Marco Sgarbi han ofrecido recientemente una nueva evaluación de las tesis continuistas tradicionales con respecto a la influencia del aristotelismo inglés en Newton y los primeros filósofos empiristas modernos. Este trabajo tiene como objetivo evaluar su impacto en los debates historiográficos actuales, y también ofrecerá algunas críticas de sus tesis principales.

Palabras clave: aristotelismo - Newton - empirismo - metodología científica - historiografía

\footnotetext{
${ }^{*}$ Received: 7 October 2013. Accepted in revised version: 2 December 2013.

+ University of Calabria, Italy. To contact the author, please write to: francescogsacco@gmail.com. Metatheoria 4(2)(2014): 53-59. ISSN 1853-2322.

(C) Editorial de la Universidad Nacional de Tres de Febrero. Publicado en la República Argentina.
} 
The books, The Main Business of Natural Philosophy: Isaac Newton's Natural-Philosophical Methodology, of Steffen Ducheyne (Ducheyne 2012) and, The Aristotelian Tradition and the Rise of British Empiricism: Logic and Epistemology in British Isles (1570-1689), of Marco Sgarbi (Sgarbi 2013) share something more than the publisher. Both deal with British empiricism and its Aristotelian background. The existence of such a background as claimed by Sgarbi, challenges the traditional prevalence of Platonism and antiAristotelianism in seventeenth-century Britain. Ducheyne, on the other hand, claims the Aristotelian roots of Newtonian methodology. According to Ducheyne, Newtonian method was very different from hypothetico-deductive methodology. Newton's use of hypothesis was part of a more general methodology divided in two phases: the construction of a model and its application including the formation and the testing of a theory (Ducheyne 2012, pp. 56-57). In this context, the nature of hypotheses changes with respect to the mechanical philosophy.

Newton was involved in the quest for a demonstrative and rigorous method till the 1680s, a decade that represents a turning point in his physical and methodological work. After the correspondence on planetary motion with Robert Hooke in 1679-1680, Newton radically changed his ideas on celestial mechanics. At the same time, his methodology reached the stage later maintained in The Principia. Mathematical Principles of Natural Philosophy (Newton [1687]1999).

Although in his early optical work Newton had clearly formulated an ideal of establishing demonstrative causes, a clear formulation of the method by which to arrive at "deductions from phenomena" was still lacking. It was only by the time of the Principia that Newton could answer this issue in a sufficiently detailed way (Ducheyne 2012, p. 184).

Newton's masterpiece of 1687 is at the centre of Ducheyne's work. In the Principia (Newton [1687]1999) the new method operated in a way that Newton was not able to reproduce in The Opticks (Newton 1730). Book I and II of the Principia offer the empirical foundation to the discussion of Keplerian laws. Newtonian's model for the explication of celestial motions according to Kepler's laws is based on the new laws of mechanics elaborated with empirical evidence in the first two books. The first phase of the method, namely the construction of the model, is completed with the elaboration of a model for Keplerian laws. In book III the second phase begins with the application of this model to the movements of celestial bodies and the formation of the theory of universal gravitation. The remaining of the Principia essentially consists in the last phase of the method, i.e. the application of the theory. Unlike Cartesian vortex hypothesis, Newtonian model is firmly based on the laws of motions. Newton refused ad hoc factors to explain discrepancies between the phenomena and the mathematical results derived from ideal conditions. Thanks to the good approximation between the laws of motions and the celestial trajectories described by planets, which entailed the absence of any relevant resistance compatible with the presence of dense ether, Newton could conclude for the inexistence of Cartesian vortexes.

According to Ducheyne (2012), the Principia's methodology is consistent with a non-mathematical concept of gravity, since it is related to a non-mechanical idea of causes. Unlike Cartesian hypothesis, causes in Newtonian model are not only explanatory but also true because they supply the necessary explanations of the observed phenomena. For Ducheyne, Newton's assumption of a causal approach is the proof of the non-mathematical origins of his methodology.

From a conceptual point of view the mathematical account of analysis and synthesis is incompatible with Newton's conception of analysis as discovering causes and of synthesis as assuming these causes to explain other phenomena. In the mathematical tradition analysis consists of reasoning from what is sought to what is known. In Newton's natural-philosophical view, analysis consisted in reasoning from what is known, the effect, to what is sought, the cause (Ducheyne 2012, pp. 7-8).

According to Ducheyne, the theory of regressus demonstrativus developed by British Aristotelians shares common features with the Newtonian method of deduction from phenomena and represents the best candidate to explain the origins of Newtonian methodology. Both are composed of two consecutive phases: analysis or resolutio, proceeding from the effects to the causes, and synthesis or compositio, 
proceeding from the causes to the effects. Furthermore, Ducheyne's thesis is supported by the evidence of Newton's direct study of a relevant Aristotelian textbook, such as Samuel Smith's Aditus ad logicam In vsum eorum qui primò Academiam salutant (Smith 1613). Thus, Aristotelian influence, along with Isaac Barrow's mathematical work, supported the Newtonian quest for a demonstrative method in natural philosophy and his refusal of the Baconian legacy embraced by the Royal Society's virtuosi.

What Ducheyne describes as the "Newtonian Style", following I. Bernard Cohen (Cohen 1982), does not work in Newtonian optics. Since the beginning of the Newtonian researches on light and colours, discrepancies between methodological demands and epistemological results emerged. Unlike Principia's laws, Newton's definition of white light as the heterogeneous mixture of coloured rays could not be deduced from experiments. According to Newtonian methodology, from the brilliant experiment of double diffraction realized in the second half of 1660 s one can only deduce that, after the decomposition of white light by the first prism, the singular coloured rays refracted by the second prism maintain their colours. "Since heterogeneity of light cannot be derived from phenomena, it qualifies as being a hypothesis according to Newton's criteria. Ultimately, Newton had only provided a sufficient cause for prismatic dispersion, not a necessary and sufficient one" (Ducheyne 2012, p.196). But for Ducheyne this is not incompatible with Newtonian style, because Newton's inference from the observable immutability of refracted coloured rays to their state before diffraction is consistent with his third regula philosophandi, the so-called analogy of nature, and with Newton's use of the so-called transduction or transdictive inference in the analysis of brief-scale attractive forces in the Principia. As Mandelbaum (1664, p. 87) and McGuire (1970, p. 4) have pointed out, since it enables to overcome the limits of experience and sense perception, inferring the unknown status of unobservable entities, the Newtonian third rule is not an induction rule. This is the case for Newtonian conclusions on the state of light rays before the first diffraction in the experimentum crucis of 1672. Attributing to coloured rays the property of immutability before the diffraction, Newton operated an inferential process similar to that described in the third rule of the Principia.

Thus Ducheyne can conclude that the epistemological problems of Newton's optical works are due to the state of the discipline and not to the high demands of his juvenile methodology. Despite Newtonian methodology evolved till the mature formulation of the Principia, the epistemological problems at the heart of his construction remained in The Opticks (Newton 1730), resisting to the Principia-style methodizing. According to Ducheyne, this is because optics did not reach the status of physico-mathematics acquired by mechanics and remained a mixed science.

Ducheyne's analysis of Newtonian optics rigorously reflects Newton's point of view. In his reconstruction, little space is conceded to the disputes following the appearance of The New Theory of light and colours in 1671 (Newton 1671). The reasons of Robert Hooke and Christian Huygens are not adequately discussed, despite the emergence of the most evident limits of Newton's early optical work is due to Hooke's criticism. As Niccolò Guicciardini observed, the methodological programme of the New Theory was "a rather extremist methodological position" (Guicciardini 2009, p.21). But, unfortunately, the way this initial position evolved till the Principia's methodology is not adequately highlighted by the book.

The Main Business of Natural Philosophy: Isaac Newton's Natural-philosophical Methodology (Ducheyne 2012) is a study of two books, or rather one, the Principia. It offers a rigorous and insightful analysis of the structure of Newton's masterpiece, but does not notice the existence of a long and complex work of elaboration and revision of Newtonian work, so relevant for the understanding of his theories. This is probably due to the author's questionable decision to restrict the analysis to the "method of justification", excluding the "method of discovery" (Ducheyne 2012, p. 63). Nevertheless, Ducheyne seems to believe that logical and methodological (British) Aristotelianism influenced Newtonian science.

Despite some initial caveats, Sgarbi maintains a similar belief about British experimental philosophy of the seventeenth century. The relationship between Paduan Aristotelianism and the new science is a topic widely discussed by historians of science. In the introduction to The Aristotelian 
Tradition and the Rise of British Empiricism, Sgarbi (2013) inclines for a moderate version of John Randall's continuist thesis (Randall 1961), because:

\begin{abstract}
Randall's argument was narrower and less ambitious» than his critics realized: «He aimed simply to demonstrate certain conceptual analogies between the thought of some Paduan Aristotelians and that of the early scientists, in their use of particular terms such as 'analysis', 'synthesis', 'induction' etc» (Sgarbi 2013, p. 4). Building on Randall's moderate programme, Sgarbi states that his book «aims to investigate how the map of Paduan Aristotelianism was replaced and absorbed into the movement known as 'British Empiricism', and not into modern science» (Sgarbi 2013, p. 6).
\end{abstract}

But by the end of the book readers apprehend that:

the emergence of experimental philosophy marked not the defeat of British logical Aristotelianism, but a strong empiricist turn in the elaboration of a new epistemology. The heirs to this tradition were Locke's precursors, who made sensation and induction the real instruments of logic: British Aristotelians no longer indulged in hypothetical and metaphysical speculations that were often untestable or inexplicable, rather emphasized that experience, acquired by observation and experiment, was the ground of science (Sgarbi 2013, p. 233).

This harmonizing view of the late Scholasticism and the new science is grounded on the empiric character of British Aristotelianism and supported by the decisive mediation of the Paduan Aristotelian Harvey and the "latent" Aristotelian Bacon and Hobbes (Sgarbi 2013, p. 197).

The insufficiency of the traditional view of British empiricism is challenged by showing the large diffusion of Aristotelian philosophy in seventeenth-century Britain. The book carefully follows the rise and fall of Ramist logic in British universities and the affirmation of Paduan Aristotelianism from the end of the sixteenth century. Sgarbi's analysis is not limited to Oxford and Cambridge, but takes into account all the universities operating in early modern British Isles. A chapter on Zabarella doctrine of induction, analysis and synthesis, precedes the accurate reconstruction of the defeat of the prevailing Ramism in British universities by means of the dissemination of Paduan textbooks, such as Giulio Pace's bilingual (Greek and Latin) edition of Aristotle's Organon of 1584, his Institutiones logicae of 1597 and his Logica rudimenta of 1612. Thanks to their propaedeutic simplicity, Pace's works were able to answer the demand of new textbooks requested by the reforms of the university statutes, such as the Laudian statutes of 1636. Furthermore, as Sgarbi accurately points out, Paduan Aristotelism reached British Isles also by means of the works of German scholars, such as Bartholomäus Kekermann. Continental textbooks offered to British scholars a new approach to the traditional peripatetic questions, and favoured the formation of a local tradition of Aristotelian thought with new features. Only in an initial phase British Aristotelianism took the shape of a simple repetition of the thesis of Zabarella. In contrast, Smith, Edward Brerewood, John Sanderson and Richard Crakanthorpe emphasized the role of the empirical part of the method developing Zabarella's theory of induction.

In the hands of the Paduan professor of natural philosophy, the Aristotelian epagôgê was not a real syllogistic demonstration, but only a clarification of things already known by sensation. Unlike demonstrative syllogism, for Zabarella induction did not demonstrate unknown things by means of prior knowledge, rather it was a "process by which particulars are comprehended under the general universal concept, but properly it does not create new knowledge beyond what the mind has already acquired by sensation" (Sgarbi 2013, p. 69). Following Zabarella, a generation of British Aristotelians emphasized the sensible origin of knowledge and the primacy of analysis on synthesis. Since analysis did not have the demonstrative nature of synthesis, it proceeded from the effects to the causes, and produced the fundaments of any possible knowledge. Then analysis would be possible without synthesis, not vice versa because analysis is the base of synthesis. This empirical foundation of knowledge is stressed by Robert Sanderson, the author of Logicae artis compendium (Sanderson 1615), a treatise read and annotated by Newton along with Smith's Aditus ad logicam (Smith 1613). For Sanderson induction is the last step of a complex process of knowledge-acquisition starting from senses perception. It consists in a sufficient enumerations of particular experiences and establishes an universal conclusion. Both Sanderson and Crackanthorpe were aware of the dangers of this kind of 
induction, because even a single case could invalidate it. Their development of Paduan tradition, stressing the importance of sensation, observation and induction, was largely dominant in British universities. The large diffusion of the new textbooks suggests the influence of this empirically-oriented Aristotelianism on British modern empiricism. But this goes beyond the chronological limits of the book. Sgarbi does not renounce, however, to take into account the relationship between the prevailing Aristotelianism and the thoughts of the English reformers of scientific knowledge, Francis Bacon, William Harvey and Thomas Hobbes. Thus, the accurate reconstruction of a neglected ancestor of modern British empiricism turns into a reappraisal of the old continuist theses. For Sgarbi, Bacon's interest for induction and his reforms is nothing else but the effects of the influence of the British scholars for the logical tools. "If Bacon focused on an inductive methodology for science, it was precisely because of the great attention which contemporary Aristotelians paid to the problem of induction and experience" (Sgarbi 2013, p. 168). In Sgarbi's eyes, Bacon's criticism of traditional induction does not entail a rejection of Aristotelian logic. On the contrary, Bacon accepted it but insisted for a strong reform (Sgarbi 2013, p. 170). His criticism of Aristotelian logic was not against Brerewood's, Sanderson's and Crackanthorpe's work, but only against Zabarella, whose concept of induction "was not really a process of discovery, but rather of notification of something already known by sensation" (Sgarbi 2013, pp. 172-3). The influence of Aristotelianism on Harvey's methodology is less problematic. Harvey's debt with Paduan tradition is well known, but it is significant that the preface to Exercitationes de generatione animalium. Quibus accedunt quaedam de partu; de membranis ac humoribus uteri; $\mathcal{E}$ de conceptione (Harvey 1651) restored the original Paduan Aristotelianism against its British developments. According to Sgarbi even the anti-scholastic Hobbes could not avoid the influence of the new British logical textbooks on a significant part of his logical theory. Although Sgarbi recognizes the experimental character of the new science and the unfamiliarity of Aristotelian philosophers with mechanical arts and their intervention in nature, he affirms that "the dissemination of the works of Bacon, Harvey and Hobbes did not make the end of the Aristotelian tradition; rather, with their latent Aristotelianism they promoted the integration of Aristotelian philosophy and the new science" (Sgarbi 2013, p. 197).

As in other similar reconstructions, such as Anstey and Vanzo (Anstey \& Vanzo 2012, pp. 509. 514), in Sgarbi's view Bacon's work is not a watershed separating the new philosophy from the old scholastic, rather it is the necessary link between them. Thus, in contrast with Ducheyne's view, Sgarbi arguments for a wide influence of British Aristotelian methodology on the whole experimental philosophy, from Baconians virtuosi to the young Newton. The contrast between Bacon's Aristotelian background claimed by Sgarbi and Bacon's idea of science drawn by leading scholars such as Mary Hesse (1968), Paolo Rossi (1984) and Brian Vickers (1992, 2007) is evident. But whatever interpretation one chooses, it is difficult to ignore the substantial inefficacy of Bacon's method along with the general insufficiency of historical positivist reconstruction which identifies modern science with the inductive method. If we look beyond their deceptive methodological statements, not any of the experimental philosophers gathered in the Royal Society really adopted Bacon's over-complicated methodology, neither did they faithfully follow his induction or his tables. On the contrary, Bacon's work passed through a process of selective reading, influenced by different cultural aims and social backgrounds. As Michael Lynch observed, the result of this process was the existence of "different styles of Baconianism" (Lynch 2001, pp. 20-21). In short, every experimental philosopher selected his own Bacon.

In early modern natural philosophy, methodological statements often do not describe the real practice of natural philosophers; instead they are a decisive argument to sustain some hypotheses and principles. In this respect, Newton's experimentum crucis is significant. In the letter of 1672 to the Royal Society, the new theory of light and colours appears as the result of a rigorous induction or rather deduction from the phenomena observed in the experiment of the double refraction. On the contrary, Newtonian unpublished optical papers suggest a different genesis of his revolutionary ideas. Between 1661 and 1664 Newton optical inquiries started with the discussion of Cartesian and Atomistic hypothesis. At this stage the young student made a first step towards a different theory, considering the 
hypothesis of a double composition of white light in fast and slow rays: dark colours originate from the slow rays, light colours from the fast ones, white, grey and black from their mixture. Despite refraction was conceived as a division of different rays, the difference itself consisted in degree of speed, and nothing in the notes suggests that Newton conceived it as an inherent and inalterable propriety of the coloured rays in white light. Is it by chance that the criticism of Cartesian physics coexists in the same notebook with a critical view of Cartesian hypotheses of light and colours? The presence in the same notebook of an atomistic commitment suggests that the genesis of Newtonian optical theories was influenced by his atomistic assumptions.

Between 1666 and 1669, Newton developed his initial hypothesis by means of a new series of experiments. The famous experimentum crucis was an instrument to develop not only his hypothesis but also to demonstrate the inconsistency of the Cartesians ones. By means of a double set of prisms Newton could then refine his hypothesis in what he presented as a theory in 1672 . As he wrote to the Royal Society, the experimentum crucis was nothing else than a "specimen" of a long series of experiments. But Newtonian narration did not refer to the hypotheses preceding the new theory. Adopting the Baconian expression of experimentum crucis, Newton described it as the result of a rigorous inductive process, a demonstrative deduction from the phenomena leaving no space to mechanic hypotheses and uncertain conjecture (Bechler 1974, p.116, Blay 1985, p. 372, Dear 1985, p. 155, Giudice 2009, pp. 69-74). The whole Newtonian theory is invested by demonstrative certainty and experimental foundation, included the assumption of the heterogeneous nature of white light. But, as Ducheyne noted, this became the greatest obstacle to the extension of the Principia's methodology to optics, because it cannot be observed at all, but only assumed on the base of a transdictive inference. Only after Hooke's criticism on this point, Newton reduced his highly methodological demand in the field of optics. It was no coincidence, that he decided to publish The Opticks (Newton 1730) only after Hooke's death in 1703.

This case does not entail the denial of any role for methodology in early modern science. Methodological ideas influenced the way scientists conceived problems and solutions in their research practice. But it is difficult to maintain the old positivist idea of an inductive method, whose origins are found in the theoretical appeal to experience, such as the Aristotelian ones emphasized by Ducheyne (2012) and Sgarbi (2013). According to this view, the complete identification of scientific practice with a codified methodology dissolves the complex nature of modern science into abstract epistemology. But methodological ideas play different roles in scientific practice, which includes among other things, the a-posteriori justification by means of clear and indisputable philosophical principles of revolutionary conclusions carried out in different ways. The revaluation of the role of methodology in post-positivist studies of science helped to understand the complex character of modern natural philosophy, whose experimental character is seemingly more dependent on the world of Renaissance mechanics, alchemy and natural magic than the Aristotelian and Scholastic theoretical empiricism. Newtonian's experimentum crucis seems to confirm that it is from the active intervention on nature, by one side, and the recourse to mathematics by the other, that so complex a thing called new science originated.

\section{References}

Anstey, P. and A. Vanzo (2012), “The Origins of Experimental Philosophy”, Intellectual History Review 22: $499-518$.

Bechler, Z. (1974), “Newton's 1672 Optical controversies: A Study in the Grammar of Scientific Dissent”, in Elkana, Y. (ed.), The Interactions between Science and Philosophy, New York: Humanities Press, pp. 115-142.

Blay, M. (1985), "Remarques sur l'influence de la pensée baconienne à la Royal Society: pratique et discours scientifiques dans l'étude des phénomènes de la couleur", Les etudes philosophiques 3: 359-374.

Cohen, I.B. (1982), The Newtonian Revolution, with Illustration of the Transformation of Scientific ideas, $2^{\text {nd }}$ edition, Cambridge: Cambridge University Press. 
Dear, P. (1985), "Totius in verba: Rhetoric and Authority in the Early Royal Society", Isis 76: 144-161.

Ducheyne, St. (2012), The Main Business of Natural Philosophy: Isaac Newton's Natural-Philosophical Methodology, Dordrecht: Springer.

Giudice, F. (2009), Lo spettro di Newton: la rivelazione della luce e dei colori, Roma: Donzelli.

Guicciardini, N. (2009), Isaac Newton on Mathematical Certainty and Method, Boston, MA, and London: The MIT Press.

Harvey, W. (1651), Exercitationes de generatione animalium. Quibus accedunt quaedam de partu; de membranis ac humoribus uteri; $\mathcal{E}$ de conceptione, Londini: apud Octavianum Pulleyn.

Hesse, M. (1968), "Francis Bacon's Philosophy of Science”, in Vickers, B. (ed.), Essential Articles for the Study of Francis Bacon, London: Sidwick \& Jackson, pp. 114-139.

Lynch, M. (2001), Solomon's Child: Method in the Early Royal Society of London, Stanford: Stanford University Press.

Mandelbaum, M. (1964), Philosophy, Science, and Sense Perception: Historical and Critical Studies, Baltimore: John Hopkins University Press.

McGuire, J.E. (1970), "Atoms and the Analogy of Nature", Studies in History and Philosophy of Science 1: 3-58.

Newton, I. (1671), "A Letter of Mr. Isaac Newton, Professor of the Mathematicks in the University of Cambridge; Containing His New Theory about Light and Colors: Sent by the Author to the Publisher from Cambridge, Febr. 6. 1671/72; In Order to Communicated to the R. Society", Philosophical Transactions 6: 3075-3087

Newton, I. (1730), The Opticks, London: William Innys.

Newton, I. (1999), The Principia. Mathematical Principles of Natural Philosophy (edited by Bernard Cohen, I. and A. Withman), Berkeley, Los Angeles and London: The University of California Press.

Randall, J. (1961), The School of Padua and the Emergence of Modern Science, Padua: Antenore.

Rossi, P. (1984), "Ants, Spiders, Epistemologists", in Fattori, M. (a cura di), Francis Bacon: terminologia e fortuna nel XVII secolo, Roma: Edizioni dell'Ateneo, pp. 245-260.

Sanderson, R. (1615), Logicae artis compendium, Oxford: J. Barnes.

Schuster, J.A. and R. Yeo (eds.) (1986), The Politics and Rhetoric of Scientific Method, Dordrecht: Reidel.

Sgarbi, M. (2013), The Aristotelian Tradition and the Rise of British Empiricism: Logic and Epistemology in British Isles (15701689), Dordrecht: Springer.

Smith, S. (1613), Aditus ad logicam In vsum eorum qui primò Academiam salutant, London: W. Stansby.

Vickers, B. (1992), "Francis Bacon and the Progress of Knowledge", Journal of the History of Ideas 53: 495-518.

Vickers, B. (2007), "Francis Bacon Mirror of each Age", in Heilbron, J. (ed.), Advancement of Learning: Essays in Honour of Paolo Rossi, Florence: Olschki, pp. 15-57. 